\title{
ANALISIS FAKTOR-FAKTOR YANG MEMPENGARUHI NILAI TANAH DI KOTA MANADO
}

\author{
Andika Presley Bintang, TRI Oldy Rotinsulu, Daisy S.M. Engka \\ Ekonomi Pembangunan - Fakultas Ekonomi dan Bisnis \\ Universitas Sam ratulangi
}

\begin{abstract}
ABSTRAK
Penelitian ini bertujuan untuk menganalisis seberapa besar pengaruh luas tanah, topografi tanah, jarak tanah ke Central Bisnis Distrik (CBD), jarak tanah ke jalan utama, dan lebar jalan disekitar lingkungan tanah berpengaruh terhadap nilai tanah. Hipotesis yang diajukan adalah bahwa luasan tanah berpengaruh negatif terhadap nilai tanah, topografi tanah yang rata mempunyai nilai yang lebih tinggi dibanding tanah dengan topografi yang tidak rata, jarak tanah ke CBD berpengaruh negatif terhadap nilai tanah, jarak tanah ke jalan utama berpengaruh negatif terhadap nilai tanah, dan lebar jalan berpengaruh positif terhadap nilai tanah, dan kontur tanah yang rata mempunyai nilai yang lebih tinggi dibanding tanah dengan kontur yang tidak rata.

Alat analisis yang digunakan dalam penelitian ini adalah regresi linier berganda. variabel dependen yaitu nilai tanah yang mengacu pada nilai hasil survei lapangan dengan beberapa penyesuaian, sedangkan variabel independen yaitu luas tanah, topografi tanah, jarak tanah ke CBD, jarak tanah ke jalan utama, dan lebar jalan.

Hasil penilaian yang diperoleh bahwa setiap pertambahan luas tanah akan aberdampak pada penurunan nilai tanah, topografi tanah yang datar memiliki nilai yang lebih ttinggi dibandingkan dengan topografi tanah yang tidak datar, setiap pertambahan jarak tanah ke CBD dan jarak tanah ke jalan utama berdampak pada penurunan nilai tanah serta pertambahan lebar jalan berdampak pada meningkatnya nilai tanah.
\end{abstract}

Kata Kunci : Nilai Tanah, Luas Bidang Tanah, Jarak Tanah Ke CBD, Jarak Tanah ke Jalan Umum, Lebar Jalan

The objective of this research is to analyze the effect of land size, the topography of the land, the land distance to the Central Business District (CBD), the distance of the main road to the ground, and the width of the road around the soil environment affect the value of the land. The hypothesis is that the area of land negatively affect the value of the land, the topography of the land is flat has a higher value than the soil and the topography is uneven, the distance of the ground to the CBD negatively affect the value of the land, a distance of ground to main roads negatively affect the value of the land and the width of the positive effect on the value of land, and the flat contour of the land has a higher value than the soil with uneven contours.

The analytical tool used in this research is multiple linear regression. the dependent variable is the value of land which refers to the value of field survey with a few adjustments, while the independent variables are spacious land, land topography, soil distance to the $\mathrm{CBD}$, within the main road to the ground, and the width of the road.

The results of the assessment obtained that any increase in the area of land will affect the decrease in the value of the soil, the flat topography has a higher value than the uneven topography of the soil, any increase in the distance of the land to the CBD and the distance of land to the main road impacts on the decrease of land value As well as the increase in the width of roads have an impact on the increasing value of land.

Kata Kunci : The Value of land, Land Size, Soil distance of CBD, distance of Main Road, road width 


\section{Latar Belakang}

\section{PENDAHULUAN}

Tanah sangat penting bagi kehidupan manusia sebagai salah satu sumberdaya alam,. Pentingnya tanah menyebabkan tanah menjadi pusat kajian bagi berbagai bidang ilmu termasuk ekonomi. Ditinjau dari aspek ekonomi tanah, Nasucha (1995:16) memandang tanah dari 2 sisi, pertama, dari sisi aspek fiskal dan administrasi pertanahan yang membahas tanah sebagai suatu objek pajak dan kedua aspek ekonomi wilayah yang menjelaskan ekonomi tanah dari investasi yang telah dilakukan untuk pengembangan wilayah yang selanjutnya diusahakan dapat mendorong ekonomi wilayah. Di pihak lain tanah merupakan sumberdaya yang jumlahnya terbatas. Keterbatasan jumlah tanah dibandingkan dengan besarnya kebutuhan akan tanah untuk berbagai fungsi (terutama dalam pemenuhan kepuasan manusia) menyebabkan nilai tanah terus meningkat.

Tanah merupakan sesuatu yang bersifat unik. Tanah mempunyai karakteristik seperti karateristik properti secara ekonomi pada umumnya yaitu immobility, durability, scarcity, dan ketika tidak didukung oleh faktor produksi lain tanah merupakan sumberdaya yang tidak produktif (Whipple, 1995:6). Konsekuensi dari tanah yang bersifat immobile adalah bahwa pasar tanah adalah terbatas (limited geographic area), incomel manfaat yang bisa dihasilkan berasal dari lokasi yang tetap (sudah fix) sehingga tidak bisa menghindari kekuatan-kekuatan eksternal yang berasal dari lokasi tersebut, tidak ada satu site pun yang serupa (inhomogeneity) dikarenakan beberapa faktor yang mempengaruhinya baik dalam hal fisik, lokasi, aksesibilitas, maupun kondisi lingkungan sekitarnya. Kondisi ini menyebabkan trend pasar dan preferensi menjadi susah dipelajari, penilaian sulit dilakukan karena kesulitan dalam melakukan perbandingan dengan jumlah transaksi sejenis yang sedikit, baik pembeli, penyewa, maupun penilai harus mendatangi properti yang bersangkutan untuk mengetahui kondisi properti dan lingkungan di sekitarnya.

Tanah dinilai atas dasar manfaat yang bisa diberikan. Tinggi rendahnya nilai tanah tergantung pada faktor-faktor yang mempengaruhinya baik faktor fisik maupun non fisik. Faktor fisik berkaitan dengan luasan, topografi, dan unsur/zat yang terkandung pada tanah. Kondisi fisik yang bagus dari tanah menandakan bahwa tanah akan dapat lebih produktif dan termanfaatkan sehingga dimungkinkan nilainya akan tinggi. Faktor lain yang berkaitan dengan nilai tanah adalah lokasi dan aksesibilitas. Lokasi dan aksesibilitas sangat berkaitan dengan "di mana" tanah itu berada. Lokasi dan akses yang menguntungkan akan membuat tanah menjadi lebih menarik dan dipandang mempunyai nilai yang tinggi. Lokasi tanah dianggap menguntungkan jika tanah tersebut berada pada pusat-pusat kegiatan ekonomi atau di mana permintaan atas tanah tersebut dimungkinkan akan terus meningkat. Hal ini dikarenakan harapan akan manfaat yang bisa dihasilkan tanah tersebut meningkat secara ekonomi.

Menurut Levy (1985:63-64) variabel utama yang menentukan nilai tanah adalah berkaitan dengan lokasi tanah yang memiliki aksessibilitas atau jarak dengan pusat kota dan pusat kegiatan ekonomi (CBD). Konsep CBD dalam hal ini diartikan lebih luas sebagai kawasan kegiatan ekonomi dalam Zona Nilai Tanah (ZNT) yang meliputi atau berkaitan dengan lokasi pusat kegiatan untuk perbelanjaan, pendidikan, perkantoran, terminal, perhotelan, tempat rekreasi dan pusat kegiatan ekonomi lainnya. Dengan adanya peningkatan transportasi, infrastruktur, sarana dan prasarana yang dibangun pemerintah 
sebagai penunjang di wilayah kota akan berdampak terhadap nilai tanah yang berada disekitar pembangunan wialyah tersebut.

\section{Rumusan Masalah}

Dengan memperhatikan uraian pada latar belakang permasalahan, maka dapat dirumuskan permasalahan dalam penelitian adalah:

1. Bagaimana luas bidang tanah mempengaruhi nilai tanah di Kota Manado?

2. Bagaimana topografi tanah mempengaruhi nilai tanah di Kota Manado?

3. Bagaimana jarak tanah ke CBD mempengaruhi nilai tanah di Kota Manado?

4. Bagaimana jarak tanah ke jalan utama mempengaruhi nilai tanah di Kota Manado?

5. Bagaimana lebar jalan di sekitar bidang tanah mempengaruhi nilai tanah di Kota Manado?

\section{Tujuan Penelitian}

Adapun tujuan yang hendak diperoleh dalam penelitian ini adalah untuk mengetahui pengaruh luas bidang tanah, topografi bidang tanah, jarak lokasi bidang tanah dengan Central Businnes Distric (CBD), jarak lokasi bidang tanah ke jalan utama, jenis dan lebar jalan di sekitar bidang tanah terhadap nilai tanah di Kota Manado.

\section{Manfaat Penelitian}

Manfaat yang diharapkan dari penelitian ini adalah:

1. Bagi Penulis, dapat dijadikan sebagai kajian dalam menentukan estimasi nilai wajar tanah dengan menggunakan pendekatan terhadap faktor-faktor yang mepengaruhi nilai tanah;

2. bagi Ilmu Pengetahuan, dapat menambah wawasan dan referensi di bidang penilaian di Indonesia;

3. Bagi Direktorat Jenderal Kekayaan Negara, dapat digunakan sebagai bahan acuan dalam rangka penilaian Barang Milik Negara/ Daerah maupun Barang Jaminan;

4. Bagi Pemerintah Provinsi Sulawesi Utara, dapat dijadikan bahan acuan dalam menentukan kebijakan dalam rangka optimalisasi Barang Milik Daerah berupa tanah;

5. Bagi Pemerintah Kota Manado khususnya Dinas Pendapatan, dapat dijadikan bahan acuan dalam menentukan nilai untuk keperluan penetapan NJOP;

6. Bagi masyarakat umum, dapat mengetahui pengaruh dan rata-rata tingkat investasi dalam menentukan keputusan berinvestasi tanah di lokasi yang sama dengan objek dalam penelitian ini.

7. Dapat dijadikan referensi bagi peneliti selanjutnya yang tertarik dengan topik ini dan kaitannya.

\section{Metode Penilaian Tanah}

\section{TINJAUAN PUSTAKA}

Sebagaimana yang dimaksudkan dalam pasal 1 ayat 3 UU Nomor 12 Tahun 1985, sebagaimana telah diubah dengan UU Nomor 12 Tahun 1994, maka dalam penilaian tanah digunakan pendekatan pendekatan perbandingan harga pasar. Metode ini adalah suatu pendekatan penilaian yang dilakukan dengan cara membandingkan antar tanah yang akan dinilai dengan tanah-tanah pembandingan yang telah diketahui karakteristik dan 
nilainya. Selanjutnya analisis dilakukan dengan mengukur tingkat kesamaan dan perbedaannya untuk menentukan beberapa penyesuain (adjustment) yang akan diberikan terhadap tanah yang akan dinilai.

Ada beberapa hal penting yang sering dipertimbangkan dalam pendekatan perbandingan harga pasar, yaitu :

a. Jenis hak yang melekat pada tanah.

b. Kondidi penjualannya.

c. Kondisi pasar.

d. Lokasi.

e. Karakteristik fisik.

f. Karakteristik-karakteristik lainnya.

Pengaruh lokasi terhadap nilai properti menjadi tinjauan dalam berbagai studi dalam kaitannya dengan atribut yang bersifat tetap atau relatip dari lokasi. Lokasi atribut yang bersifat tetap dikuantitatifkan dengan penghargaannya terhadap keseluruhan area perkotaan, salah satunya diukur dengan aksesibilitas (Follain \& Jimenez, 1985; Orford, 1988). Atribut relatif lokasi diukur dengan klas ekonomi sosial, komposisi rasial, atribut yang bersifat estetik, tingkat polusi, serta proximity kepada prasarana lokal. (Dubin \& Sung, 1990 dalam Bjorklund 2009).

\section{Kerangka Pemikiran Teoritis}

Kerangka pemikiran penelitian adalah sebagai berikut

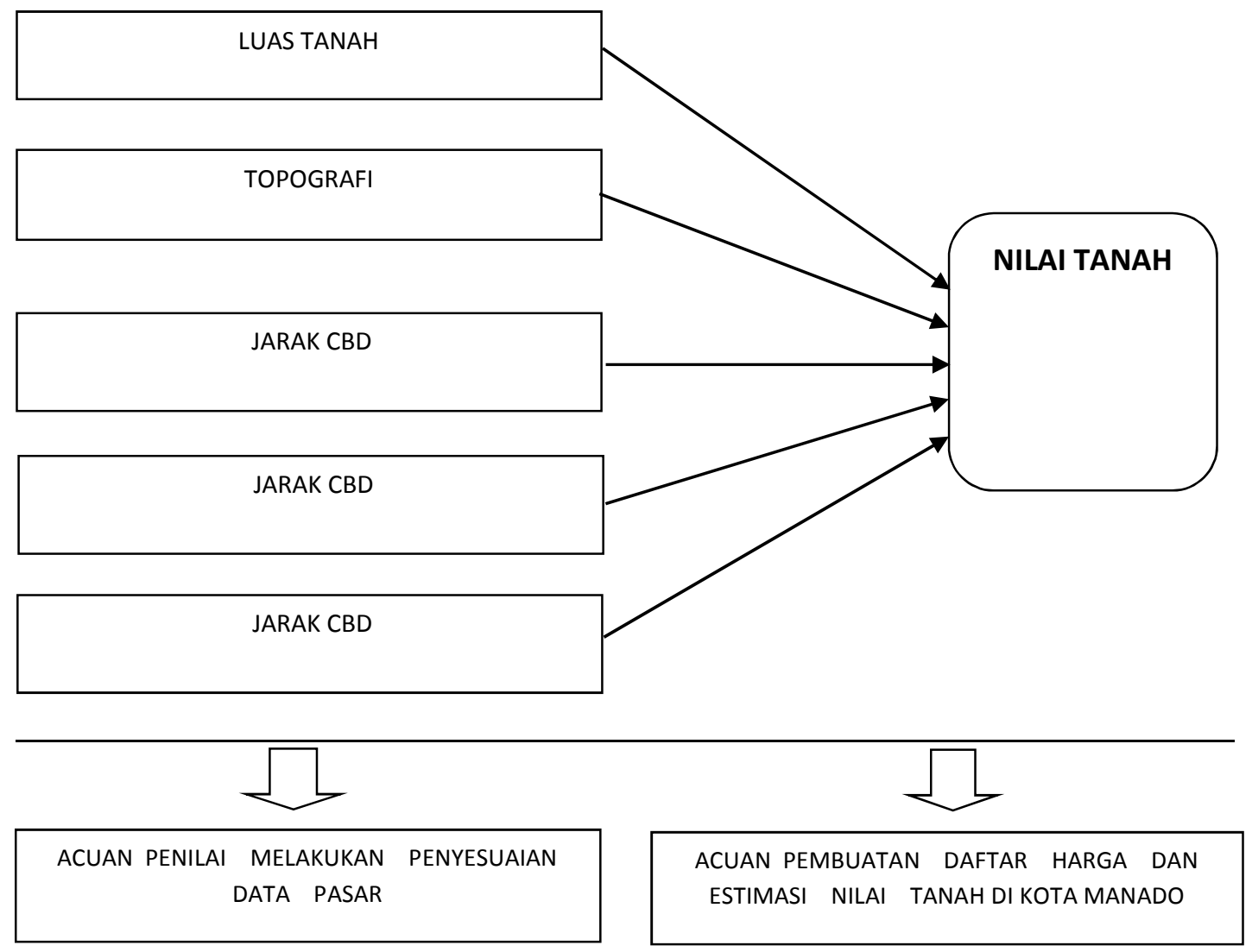




\section{Hipotesis}

Berdasarkan landasan teori dan pemilihan variabel yang dituangkan dalam kerangka konsep disesuaikan dengan kharateristik lokasi penelitian, maka ditarik hipotesis penelitian sebagai berikut :

1. Luasan tanah yang dijual berpengaruh negatif terhadap nilai tanah per meter persegi;

2. Topografi Tanah berpegaruh positif terhadap nilai tanah per meter persegi;

3. Jarak tanah ke CBD berpengaruh negatif terhadap nilai tanah per meter persegi;

4. Jarak tanah ke jalan utama berpengaruh negatif terhadap nilai tanah per meter persegi;

5. Lebar Jalan di sekitar bidang tanah berpengaruh positif terhadap nilai tanah per meter persegi.

\section{Jenis Penelitian}

\section{METODE PENELITIAN}

Jenis penelitian ini adalah penelitian kuantitatif. Metode dalam analisis yang digunakan dalam penelitian ini adalah adalah metode analisis kuantitatif, yaitu dalam menarik kesimpulan didasarkan pada perhitungan statistik dan matematis. Variabel penelitian diukur dalam satuan ukuran tertentu dan diukur dengan skala nominal. Apabila terdapat suatu variabel penelitian berupa variabel kualitatip, maka ukuran kualitatip tersebut dikonversi menjadi ukuran kuantitatif dan diukur dengan skala ordinal (diskrit).

\section{Jenis dan Sumber Data}

Jenis data yang dipergunakan dalam penelitian ini adalah data primer dengan satuan pengukuran dalam satuan nominal dan satuan ordinal. Data primer dalam penelitian ini didapatkan langsung berdasarkan pengamatan peneliti melalui wawancara serta meminta informasi kepada pemilik tanah, pengembang, serta penghuni dan pekerja formal/informal (petugas pemungut PBB pada kelurahan, satpam, dan pembantu) di sekitar lokasi bidang tanah yang dijadikan sampel penelitian. Rekap transaksi jual beli oleh PPAT notaris juga dijadikan sumber data awal dalam penelitian ini, namun tetap harus dikonfirmasi dan dituangkan dalam formulir survei data lapangan.

\section{Operasional Variabel dan Alat Analisis Data Defenisi Operasional Variabel}

Adapun variabel varibel yang digunakan dalam penelitian adalah :

$$
\begin{aligned}
& \text { NLIA } \left.=\text { Nilai Tanah per } \mathrm{m}^{2} \text { (dalam satuan mata uang rupiah }\right) \\
& \text { LUAS }=\text { Luas tanah (dalam satuan meter persegi) } \\
& \text { TPGF }=\text { Topografi (data diskrit) } \\
& \text { JCBD }=\text { Jarak dengan CBD (dalam satuan meter) } \\
& \text { JJLU }=\text { Jarak ke Jalan Utama (dalam satuan meter) } \\
& \text { LBJL }=\text { Lebar Jalan (dalam satuan meter) }
\end{aligned}
$$


Definisi operasional adalah suatu definisi yang memberkan penjelasan atas suatu bentuk yang dapat diukur. Definisi ini memberikan informasi yang diperlukan untuk mengukur variabel yang akan diteliti. Definisi operasional variabel dalam penelitian adalah sebagai berikut:

1. Nilai Tanah, adalah nilai pasar wajar dari suatu properti untuk diperjual belikan atau ditawarkan pada pasar properti dalam satuan mata uang rupiah per meter persegi.

2. Luas tanah adalah luas tanah data transaksi dalam satuan meter persegi.

3. Topografi diukur dengan kontur tanah pada daerah penelitian. Nilai skor (1) apabila merupakan daerah datar. Nilai skor (2) apabila merupakan daerah yang sedikit bergelombang (kemiringan $<10^{0}$ ) Nilai skor (3) apabila merupakan daerah yang bergelombang sedang $\left(10^{\circ}<\right.$ kemiringan $\left.<30^{\circ}\right)$. Nilai skor (4) apabila merupakan daerah yang bergelombang kuat $\left(30^{\circ}<\right.$ kemiringan $\left.<45^{\circ}\right)$. Nilai skor (5) apabila merupakan daerah yang terjal atau berupa tebing $\left(45^{\circ}<\right.$ kemiringan $\left.<90^{\circ}\right)$.

4. Jarak ke Central Bussines District (CBD) adalah jarak tempuh yang diukur dari lokasi ke Central Bussines District. Yaitu diukur ke daerah sekitar CBD terdekat dalam satuan meter.

5. Jarak ke jalan utama diukur dari jarak tempuh dari lokasi ke jalan yang dilewati angkutan umum (jalan protokol, jalan bisnis atau jalan desa/lingkungan) dalam satuan meter.

6. Lebar jalan diukur dengan lebar jalan pada lokasi objekdalam satuan meter.

\section{Alat Analisis Data}

Analisis regresi berganda yang digunakan adalah model regresi semilog dimana hanya salah satu variabel (varibel independen atau varibel dependen) yang ditransformasi secara logaritma yang bertujuan untuk memperoleh suatu persamaan dan garis yang menunjukan hubungan antara dua variabel atau lebih dan untuk menaksir satu variabel (variabel independen) dengan variabel lainnya (variabel dependen).

Melalui analisis tersebut dapat dibuktikan ada tidaknya hubungan fungsional atau hubungan kausal antara dua atau lebih variabel bebas $X_{1}, X_{2}, \ldots, X_{n}$ terhadap suatu variabel terikat Y.

Dengan merujuk pada model regresi tersebut, maka penelitian ini menggunakan model regresi sebagai berikut:

$$
\begin{aligned}
& \log (\mathrm{NLAI})=\alpha 0+\alpha 1 \mathrm{LUAS}+\alpha 2 \mathrm{TPGF}+\alpha 3 \mathrm{JCBD}+\alpha 4 \mathrm{JJLU}+\alpha 4 \mathrm{LBJL}+\varepsilon \mathrm{i} \\
& \text { Di mana: } \\
& \text { NLAI }=\text { Nilai Tanah }(\mathrm{Rp}) \\
& \alpha_{0}=\text { Konstanta } \\
& \alpha 1 . . \alpha 5=\text { Koefisien variabel } \\
& \text { LUAS }=\text { Luas tanah }\left(\mathrm{m}^{2}\right) \\
& \text { TPGF }=\text { Topografi }(\text { ordinal } 1,2,3,4,5) \\
& \mathrm{JCBD}=\text { Jarak dengan CBD }(\mathrm{m}) \\
& \text { JJLU }=\text { Jarak ke Jalan Utama }(\mathrm{m}) \\
& \text { LBJL = Lebar Jalan }(\mathrm{m}) \\
& \varepsilon_{\mathrm{i}} \quad=\text { Error term }
\end{aligned}
$$




\section{Uji Ekonometrik (Asumsi Klasik)}

1. Uji normalitas. Uji normalitas dilakukan untuk memenuhi asumsi klasik bahwa distribusi probabilitas dari faktor pengganngu mempunyai nilai rata-rata yang diharapkan sama dengan 0, tidak berkorelasi, dan mempunyai varian yang konstan. Dengan asumsi ini OLS estimator dari persamaan akan memenuhi sifat-sifat statistik yang diinginkan seperti ketidakbiasan, dan mempunyai varian yang minimum.

Uji normalitas dilakukan dengan Jarque-Bera test ( $\mathrm{J}-\mathrm{B}$ test) yaitu dengan membandingkan antara nilai J-B hitung hasil estimasi residual dan chi-square probability distribution (tabel chi-square) dengan df 2 dengan pedoman sebagai berikut (Insukindro, 2001).

a. Bila nilai J-B hitung > nilai pada tabel chi-square maka hipotesis yang menyatakan bahwa residual yang menyatakan residual berdistribusi normal ditolak.

b. Bila nilai J-B hitung < nilai pada tabel chi-square maka hipotesis yang menyatakan bahwa residual yang menyatakan residual berdistribusi normal tidak dapat ditolak. Hasil uji normalitas akan dibahas pada bab selanjutnya.

2. Uji autokorelasi. Istilah autokorelasi dapat didefinisikan sebagai korelasi antara anggota serangkaian observasi yang diurutkan baik menurut waktu (time series) atau ruang (cross section). Uji autokorelasi perlu dilakukan berkenaan dengan adanya asumsi klasik yang menyatakan bahwa unsur gangguan yang berhubungan dengan observasi tidak dipengaruhi oleh unsur gangguan yang berhubungan dengan pengamatan lain dimanapun (Gujarati, 2004:201). Pendeteksian adanya masalah autokorelasi dalam suatu model bisa dilakukan dengan berbagai uji. Pada penulisan ini uji terhadap autokorelasi dilakukan dengan Uji Lagrange Multiplier (LM test) yang mengidentifikasi masalah autokorelasi tidak hanya pada derajat pertama. Pedoman pengujian adalah sebagai berikut.

a. Bila nilai $\left(n * \mathrm{R}^{2}\right)<$ nilai pada tabel chi-square maka menerima hipotesis yang mengatakan bahwa tidak terdapat masalah autokorelasi dalam model yang sedang diestimasi.

b. Bila nilai $\left(\mathrm{n}^{*} \mathrm{R}^{2}\right)>$ nilai pada tabel chi-square maka menolak hipotesis yang mengatakan bahwa tidak terdapat masalah autokorelasi dalam model yang sedang diestimasi.

Hasil uji autokorelasi dibahas pada bab selanjutnya.

3. Uji multikolinieritas. Multikolinieritas adalah keadaan dimana satu atau lebih variabel bebas merupakan persaman linear dari variabel bebas lainnya (Gujarati, 2004:157). Adanya multikolinieritas menyebabkan standard error semakin membesar dengan meningkatnya tingkat korelasi antarvariabel.

Cara untuk mendeteksi adanya multikolinieritas diantaranya adalah dengan melihat nilai $\mathrm{R}^{2}$, jika $\mathrm{R}^{2}$ besar tetapi hasil $\mathrm{t}$ statistik variabel independen sedikit yang signifikan diindiasikan terdapat masalah multikolinieritas dalam model. Cara lain adalah dengan melihat koefisien korelasi antarvariabel independen. Jika koefisien korelasi tinggi (diatas 0,8) maka diindikasikan terdapat masalah multikolinieritas (Gujarati, 2003: 359). Hasil uji multikolinieritas dibahas pada bab selanjutnya.

4. Uji heteroskedastisitas. Uji ini digunakan untuk melihat apakah kesalahan pengganggu mempunyai varian yang sama atau tidak. Masalah heteroskedastisitas menyebabkan penaksir OLS tidak efisien baik dalam sampel kecil maupun sampel besar tapi masih tetap tidak bias dan konsisten. 
Salah satu cara untuk mengetahui ada tidaknya heteroskedastisitas adalah dengan cara white test. Pedoman dalam penggunaan uji White adalah:

1. bila nilai $\left(\mathrm{n}^{*} \mathrm{R}^{2}\right)<$ nilai pada tabel chi-square maka menolak hipotesis yang mengatakan bahwa terdapat masalah heteroskedastisitas dalam model yang sedang diestimasi;

2. bila nilai $\left(\mathrm{n}^{*} \mathrm{R}^{2}\right)>$ nilai pada tabel chi-square maka menolak hipotesis yang mengatakan bahwa tidak terdapat masalah heteroskedastisitas dalam model yang sedang diestimasi.

Hasil uji heteroskedastisitas dibahas pada bab selanjutnyaterhadap variabel bebas yang diduga sebagai penyebab dari heterokedastisitas. Suatu model mengandung heterokedastisitas apabila nilai residunya membentuk pola sebaran yang meningkat, yaitu secara terus menerus bergerak menjauhi garis nol.

\section{Uji Statistik}

1. Uji t (uji parsial). Uji t digunakan untuk mengetahui tingkat signifikansi dari masing-masing koefisien regresi

Hipotesis : Ho : $\alpha_{1}=0$

$$
\mathrm{H}_{1}: \alpha_{1} \neq 0
$$

$\mathrm{T}$ tabel : $\mathrm{t}^{\alpha / 2} ; \mathrm{N}-\mathrm{K} ; \alpha$ adalah derajat signifikansi, $\mathrm{N}$ adalah jumlah sampel/observasi, dan $\mathrm{K}$ adalah banyaknya parameter

$$
\text { thitung }=\frac{b_{i}}{\operatorname{se}\left(b_{i}\right)}
$$

Jika $-\mathrm{t}$ tabel $<\mathrm{t}$ hitung $>+\mathrm{t}$ tabel, maka $\mathrm{H}_{0}$ diterima dan menolak $\mathrm{H}_{1}$. Hal ini berarti secara signifikan variabel independen tidak berpengaruh terhadap variabel dependen pada tingkat $\alpha$. Hal yang sama dapat ditentukan ketika hasil pengolahan memperlihatkan nilai prob $>\alpha$, dan sebaliknya ketika t hitung $<-\mathrm{t}$ tabel atau $\mathrm{t}$ hitung $>+\mathrm{t}$ tabel berarti bahwa variabel independen secara statistik berpengaruh terhadap variabel dependen pada tingkat $\alpha$ atau prob $<\alpha$. Hasil uji t dibahas pada bab selanjutnya.

2. Uji F (analisis varian). Uji ini digunakan untuk menguji signifikansi secara bersama-sama atas semua koefisien regresi.

Hipotesis : Ho: $\alpha_{1}=\alpha_{2}=\alpha_{2}=\alpha_{2}=\alpha_{2}=0$

$$
H_{1}: \alpha_{1} \neq \alpha_{2} \neq \alpha_{3} \neq \alpha_{4} \neq \alpha_{5} \neq
$$

F tabel : $\alpha ; \mathrm{N}-\mathrm{K}: \mathrm{K}-1$

$$
\text { Fhitung }=\frac{R^{2} /(k-1)}{\left(1-R^{2}\right) / N-K}
$$

Jika $\mathrm{F}$ hitung $>\mathrm{F}$ tabel berarti Ho ditolak dan menerima $\mathrm{H}_{1}$ berarti dapat disimpulkan bahwa semua variabel independen secara bersama-sama berpengaruh terhadap variabel dependen pada taraf $\alpha$ hal serupa dapat diketahui jika nilai prob (F stat) $<\alpha$, sebaliknya ketika $\mathrm{F}$ hitung $<\mathrm{F}$ tabel maka dapat dikatakan bahwa variabel independen tidak signifikan berpengaruh terhadap variabel dependen pada taraf $\alpha$ atau $\operatorname{Prob}(\mathrm{F}$ stat $)>\alpha$. Hasil uji $\mathrm{F}$ dibahas pada bab selanjutnya.

3. Koefisien determinasi $\left(\mathbf{R}^{2}\right)$. $\mathrm{R}^{2}$ merupakan alat ukur kebaikan-suai (goodness of fit) dari persamaan regresi yang meenyatakan berapa besar proporsi variasi variabel dependen dapat dijelaskan oleh variabel independen. Besarnya $\mathrm{R}^{2}$ akan diketahui setelah melakukan analisis pada bab selanjutnya 


\section{Hasil Analisis Data dan Pembahasan \\ Bentuk Fungsi Model}

\section{HASIL PENELITIAN DAN PEMBAHASAN}

Pemilihan fungsi model yang tepat didasarkan atas pengujian berbagai bentuk fungsi model yaitu bentuk regresi log-linier, terhadap kondisi linieritas, normalitas, dan tingkat signifikansi variabel (hasil selengkapnya baca lampiran penelitian). Bentuk persamaan menjadi:

$$
\log (N L A I)=a+b_{1} L U A S+b_{2} T P G F+b_{3} J C B D+b_{4} J J L U+b_{5} L B J L
$$

NLAI = nilai; LUAS = luas tanah; TPGF $=$ Topografi Tanah; JCBD = jarak tanah ke CBD terdekat; JJLU = jarak tanah ke jalan utama; LBJL = lebar jalan.

Hasil analisis dengan menggunakan Program Eviews (lampiran) adalah sebagai berikut:

\section{Tabel 1 Hasil Analisis Regresi Linier Berganda}

Dependent Variable: LOG(NILAI)

Method: Least Squares

Date: 04/11/17 Time: 23:49

Sample: 175

Included observations: 75

\begin{tabular}{crcrr}
\hline \hline Variable & Coefficient & Std. Error & t-Statistic & Prob. \\
\hline \hline C & 13.03777 & 0.445048 & 29.29521 & 0.0000 \\
LUAS & -0.000295 & $4.34 \mathrm{E}-05$ & -6.789447 & 0.0000 \\
TPGF & 0.246065 & 0.097258 & 2.530038 & 0.0137 \\
JCBD & -0.000351 & $5.37 \mathrm{E}-05$ & -6.523294 & 0.0000 \\
LBJL & -0.000726 & 0.000123 & -5.893904 & 0.0000 \\
R-squared & 0.073789 & 0.026339 & 2.801472 & 0.0066 \\
Adjusted R-squared & 0.808607 & Mean dependent var & 13.52728 \\
S.E. of regression & 0.794738 & S.D. dependent var & 0.997517 \\
Sum squared resid & 0.451933 & Akaike info criterion & 1.326052 \\
Log likelihood & 14.09279 & Schwarz criterion & 1.511451 \\
F-statistic & -43.72696 & Hannan-Quinn criter. & 1.400080 \\
Prob(F-statistic) & 58.30313 & Durbin-Watson stat & 2.025674 \\
\hline \hline
\end{tabular}

Sumber: hasil olahan, lihat lampiran

\section{Uji Ekonometrika (Asumsi Klasik)}

Beberapa uji asumsi klasik yang dilakukan adalah uji normalitas, multikolinieritas, heteroskedastisitas, dan autokorelasi.

1. Uji Normalitas. Uji normalitas dilakukan dengan Jarque-Bera test (J-B test) yaitu dengan membandingkan antara nilai J-B hitung hasil estimasi residual dan chi-square probability distribution (tabel chi-square) dengan df 2 dengan pedoman sebagai berikut. 
1. Bila nilai J-B hitung > nilai pada tabel chi-square maka hipotesis yang menyatakan bahwa residual yang menyatakan residual berdistribusi normal ditolak.

2. Bila nilai J-B hitung < nilai pada tabel chi-square maka hipotesis yang menyatakan bahwa residual yang menyatakan residual berdistribusi normal tidak dapat ditolak.

Hasil uji normalitas pada lampiran menunjukkan nilai J-B hitung pada $\alpha=0,05$ sebesar 0,488 dan nilai pada tabel chi-square adalah 95,08. Hasil ini membuktikan bahwa residual telah terdistribusi normal.

2. Multikolinieritas. Cara untuk mendeteksi adanya multikolinieritas di antaranya adalah jika $\mathrm{R}^{2}$ besar tetapi hasil $\mathrm{t}$ statistik variabel independen sedikit yang signifikan. Hasil regresi pada tabel menunjukkan bahwa hal ini tidak ditemui pada persamaan di atas. Cara lain yang bisa digunakan adalah dengan melihat korelasi antara variabel independen sangat besar (di atas 0,8). Berikut ini adalah matrik korelasi antara variabel independen.

Tabel 2 Matrik Korelasi

\begin{tabular}{|c|r|r|r|r|r|}
\hline Variabel & \multicolumn{1}{|c|}{ LUAS } & \multicolumn{1}{c|}{ TPGF } & \multicolumn{1}{c|}{ JCBD } & \multicolumn{1}{c|}{ JJLU } & \multicolumn{1}{c|}{ LBJL } \\
\hline LUAS & 1,000 & $-0,106$ & $-0,112$ & 0,045 & $-0,279$ \\
\hline TPGF & $-0,106$ & 1,000 & 0,156 & 0,026 & 0,214 \\
\hline JCBD & $-0,112$ & 0,156 & 1,000 & 0,140 & $-0,516$ \\
\hline JJLU & 0,045 & 0,026 & 0,140 & 1,000 & $-0,434$ \\
\hline LBJL & $-0,279$ & 0,214 & $-0,516$ & $-0,434$ & 1,000 \\
\hline
\end{tabular}

Sumber: hasil olahan, lihat lampiran

Dari hasil di atas tidak ditemukan korelasi antara variabel independen yang sangat tinggi (di atas 0,8). Dari hasil ini dapat disimpulkan bahwa tidak terdapat multikolinieritas di antara variabel independen.

3. Heteroskedastisitas. Cara pendeteksian heteroskedastisitas dilakukan dengan uji White dengan menggunakan regresi bantuan (lampiran). Pedoman dalam penggunaan uji White adalah:

3. Bila nilai $\left(n * \mathrm{R}^{2}\right)<$ nilai pada tabel chi-square maka menolak hipotesis yang mengatakan bahwa terdapat masalah heteroskedastisitas dalam model yang sedang diestimasi.

4. Bila nilai $\left(\mathrm{n}^{*} \mathrm{R}^{2}\right)>$ nilai pada tabel chi-square maka menolak hipotesis yang mengatakan bahwa tidak terdapat masalah heteroskedastisitas dalam model yang sedang diestimasi. 


\section{Tabel 3 Hasil Uji Heteroskeditas}

Heteroskedasticity Test: White

\begin{tabular}{llll}
\hline \hline & & & \\
F-statistic & 6.350623 & Prob. F(20,54) & 0.0000 \\
Obs*R-squared & 52.62585 & Prob. Chi-Square(20) & 0.0001 \\
Scaled explained SS & 53.14546 & Prob. Chi-Square(20) & 0.0001 \\
\hline \hline
\end{tabular}

Test Equation:

Dependent Variable: RESID^2

Method: Least Squares

Date: 04/12/17 Time: $15: 46$

Sample: 175

Included observations: 75

\begin{tabular}{llll}
\hline \hline F-statistic & 6.350623 & Durbin-Watson stat & 2.186215 \\
Prob(F-statistic) & 0.000000 & & \\
\hline \hline
\end{tabular}

Sumber: hasil olahan, lihat lampiran

Dari hasil pengujian di atas didapatkan hasil bahwa nilai $n * R^{2}$ adalah 52,62 dan nilai pada tabel chi-square adalah 95,08 yang berarti bahwa $\left(\mathrm{n}^{*} \mathrm{R}^{2}\right)<$ nilai pada tabel chi-square atau tidak terjadi masalah heteroskedastisitas.

4. Autokorelasi. Uji terhadap autokorelasi dilakukan dengan Uji Lagrange Multiplier (LM test) yang mengidentifikasi masalah autokorelasi tidak hanya pada derajat pertama. Pedoman pengujian adalah sebagai berikut.

c. Bila nilai $\left(n * \mathrm{R}^{2}\right)<$ nilai pada tabel chi-square maka menerima hipotesis yang mengatakan bahwa tidak terdapat masalah autokorelasi dalam model yang sedang diestimasi.

d. Bila nilai $\left(\mathrm{n}^{*} \mathrm{R}^{2}\right)>$ nilai pada tabel chi-square maka menolak hipotesis yang mengatakan bahwa tidak terdapat masalah autokorelasi dalam model yang sedang diestimasi. 
Tabel 4 Hasil Uji Autokolerasi

Breusch-Godfrey Serial Correlation LM Test:

\begin{tabular}{llll}
\hline \hline F-statistic & 0.048619 & Prob. F(2,67) & 0.9526 \\
Obs*R-squared & 0.108691 & Prob. Chi-Square(2) & 0.9471 \\
\hline \hline
\end{tabular}

Test Equation:

Dependent Variable: RESID

Method: Least Squares

Date: 04/13/17 Time: 03:13

Sample: 175

Included observations: 75

Presample missing value lagged residuals set to zero.

Sumber: hasil olahan, lihat lampiran

Pada hasil LM test pada Tabel 4. didapatkan nilai $n * R^{2}$ sebesar 0,108691 dan nilai pada tabel chi-square sebesar 95,08 yang berarti bahwa nilai $\left(\mathrm{n} * \mathrm{R}^{2}\right)<$ nilai pada tabel chisquare atau dengan kata lain menerima hipotesis yang mengatakan bahwa tidak terdapat masalah autokorelasi dalam model yang sedang diestimasi.

\section{Uji statistic}

1. Uji t. Uji t digunakan untuk mengetahui tingkat signifikansi dari masing-masing koefisien regresi

Hipotesis : $\mathrm{H}_{\mathrm{o}}: \mathrm{b}=0$

$$
\mathrm{H}_{1}: \mathrm{b} \neq 0
$$

T tabel $(0,05, \mathrm{df}=74)=1,66571$

Ketika $t$ hitung $<-\mathrm{t}$ tabel atau $\mathrm{t}$ hitung $>+\mathrm{t}$ tabel berarti bahwa variabel independen secara statistik berpengaruh terhadap variabel dependen pada tingkat $\alpha$ atau prob $<\alpha$.

Dari tabel dapat disimpulkan kondisi signifikansi dari masing-masing variabel independen pada $\alpha=0,05$ adalah sebagai berikut.

\begin{tabular}{|c|c|c|c|c|}
\multicolumn{9}{|c|}{ Tabel 5 Hasil Uji-t } \\
\hline Variabel & t-Statistic & $\mid$ t-table $\mid$ & Prob. & Keterangan \\
\hline LUAS & -6.789447 & 1,66 & 0.0000 & $\begin{array}{c}\mathrm{H}_{\mathrm{o}} \text { ditolak, } \mathrm{H}_{1} \text { diterima } \\
\text { signifikan berpengaruh terhadap nilai }\end{array}$ \\
\hline TPGF & 2.530038 & 1,66 & 0.0000 & $\begin{array}{c}\mathrm{H}_{\mathrm{o}} \text { ditolak, } \mathrm{H}_{1} \text { diterima } \\
\text { signifikan berpengaruh terhadap nilai }\end{array}$ \\
\hline JJLU & -6.523294 & 1,66 & 0.0137 & $\begin{array}{c}\mathrm{H}_{\mathrm{o}} \text { ditolak, } \mathrm{H}_{1} \text { diterima } \\
\text { signifikan berpengaruh terhadap nilai }\end{array}$ \\
\hline LBJL & 2.801472 & 1,66 & 0.0000 & $\begin{array}{c}\mathrm{H}_{\mathrm{o}} \text { ditolak, } \mathrm{H}_{1} \text { diterima } \\
\text { signifikan berpengaruh terhadap nilai }\end{array}$ \\
\hline
\end{tabular}

Sumber: hasil olahan, lihat lampiran 
2. Uji F. Uji ini digunakan untuk menguji signifikansi secara bersama-sama atas semua koefisien regresi.

Hipotesis : Ho : $b_{1}=b_{2}=0$

$$
\mathrm{H}_{1}: \mathrm{b}_{1} \neq \mathrm{b}_{2} \neq
$$

F tabel : $0.05 ; 75 ; 5=2.34$

Jika $\mathrm{F}$ hitung $>\mathrm{F}$ tabel berarti Ho ditolak dan $\mathrm{H}_{1}$ diterima berarti dapat disimpulkan bahwa semua variabel independen secara bersama-sama berpengaruh terhadap variabel dependen pada taraf 0,05. Dari hasil regresi table 4.1 didapatkan nilai $F$ hitung sebesar 58.30313 yang berarti $\mathrm{F}$ hitung $>\mathrm{F}$ tabel atau dengan kata lain $\mathrm{H}_{\mathrm{o}}$ ditolak dan $\mathrm{H}_{1}$ diterima, dapat disimpulkan bahwa semua variabel independen yaitu luas, topografi, jarak tanah ke CBD, jarak ke jalan utama dan lebar jalan secara bersama-sama berpengaruh terhadap variabel dependen yaitu nilai tanah pada taraf 0,05 .

3. Koefisien Determinasi $\left(\mathbf{R}^{2}\right)$. $R^{2}$ menyatakan berapa besar proporsi variasi variabel dependen dapat dijelaskan oleh variabel independen. Dari hasil tabel 4.1 dapat dilihat besarnya $\mathrm{R}^{2}=0.808607$ yang berarti bahwa $80,86 \%$ variasi variabel nilai tanah dapat dijelaskan oleh luas, topografi, jarak tanah ke CBD, jarak ke jalan utama dan lebar jalan, sisanya sebesar 19,14\% dijelaskan oleh variabel lain di luar model.

\section{Intrepetasi Hasil}

Intrepetasi hasil regresi secara ekonomi ditentukan oleh prinsip-prinsip dalam teori ekonomi yang mencakup pengujian terhadap tanda maupun nilai koefisien dari masingmasing variabel yang diestimasi. Persamaan yang dihasilkan pada tabel 4.1 dapat disimpulkan sebagai berikut.

\section{$\log (\mathrm{NLAI})=13,03777-0,000295 \mathrm{LUAS}+0,246065$ TPGF $-0,000351$ JCBD - 0,000726 JJLU + 0,073789 LBJLN}

1. Pengaruh luasan tanah terhadap nilai tanah. Dari hasil uji t tabel 4.5 luasan tanah per meter berpengaruh signifikan terhadap nilai tanah pada $\alpha=0,05$. Besaran pengaruh luas tanah terhadap nilai tanah didapatkan dari rumus (antilog koefisien luas tanah - 1) x 100 (Gujarati, 2003:333). Dari tabel 4.1 koefisien luas tanah sebesar -0,000295, maka besar pengaruh luas tanah terhadap nilai tanah adalah sebesar $(0,993-1) \times 100=-0,7 \%$.

2. Pengaruh topografi terhadap nilai tanah. Hasil uji t menunjukkan bahwa topografi tanah berpengaruh signifikan terhadap nilai tanah. Tanda positif pada kontur tanah menunjukkan bahwa topografi tanah yang rata $(D=1)$ memiliki nilai yang lebih tinggi dibanding dengan nilai tanah yang tidak rata. Prosentase perbedaan nilai tanah rata dan nilai tanah yang tidak rata didapatkan dari rumus (antilog koefisien topografi tanah - 1) x 100 (Gujarati, 2003:333). Dari tabel 4.1 koefisien kontur tanah sebesar 0,246065, maka perbedaan antara nilai tanah yang rata dan tidak rata adalah sebesar $(100,657759-$ 1) $\mathrm{x} 100=76,22 \%$.

3. Pengaruh jarak tanah ke CBD terhadap nilai tanah. Hasil uji t tabel 4.5 jarak tanah ke CBD berpengaruh signifikan terhadap nilai tanah pada $\alpha=0,05$. Besaran pengaruh jarak tanah ke CBD terhadap nilai tanah didapatkan dari rumus (antilog koefisien jarak tanah ke CBD - 1) x 100 (Gujarati, 2003:333). Dari tabel 4.1 koefisien jarak tanah ke 
CBD sebesar -0,000351, maka besar pengaruh jarak tanah ke CBD terhadap nilai tanah adalah sebesar $(0,999-1) \times 100=-0,1 \%$.

4. Pengaruh jarak tanah ke jalan utama terhadap nilai tanah. Hasil uji t tabel 4.5 jarak tanah ke jalan utama berpengaruh signifikan terhadap nilai tanah pada $\quad \alpha=0,05$. Besaran pengaruh jarak tanah ke jalan utama terhadap nilai tanah didapatkan dari rumus (antilog koefisien jarak jalan utama - 1) x 100 (Gujarati, 2003:333). Dari tabel 4.1 koefisien jarak jalan utama sebesar -0,000726, maka besar pengaruh jarak tanah ke jalan utama terhadap nilai tanah adalah sebesar $(0,998-1) \times 100=-0,2 \%$.

5. Pengaruh lebar jalan terhadap nilai tanah. Hasil uji t tabel 4.5 lebar jalan berpengaruh signifikan terhadap nilai tanah pada $\alpha=0,05$. Besaran pengaruh lebar jalan terhadap nilai tanah didapatkan dari rumus (antilog koefisien lebar jalan - 1) x 100 (Gujarati, 2003:333). Dari tabel 4.1 koefisien lebar jalan sebesar 0,073789, maka besar pengaruh lebar jalan terhadap nilai tanah adalah sebesar $(1,185-1)$ x $100=18,51 \%$.

6. Pegaruh variabel bebas terhadap variabel terikat. Hasil uji-f membuktikan bahwa luas tanah, topografi, jarak tanah ke CBD, jarak tanah ke jalan utama dan lebar jalan secara bersama-sama berpengaruh signifikan terhadap nilai tanah pada tingkat $\alpha=0,05$ dengan besaran $\mathrm{R}^{2}=0.808607$. Hal ini menegaskan bahwa $80,86 \%$ variasi nilai tanah dapat dijelaskan oleh variabel luas tanah, topografi, jarak tanah ke CBD, jarak ke jalan utama dan lebar jalan, sisanya sebesar 19,14\% dijelaskan oleh variabel lain di luar model yang diteliti.

\section{Pembahasan Hasil}

Nilai tanah dipengaruhi secara signifikan oleh faktor luas tanah, topografi bidang tanah, jarak tanah ke CBD, jarak tanah ke jalan utama, dan lebar jalan . Berdasarkan hasil analisis regresi model semi log yang dirumuskan pada Intrepretasi Hasil di perohel hasil uji ekonometrika sebagai berikut:

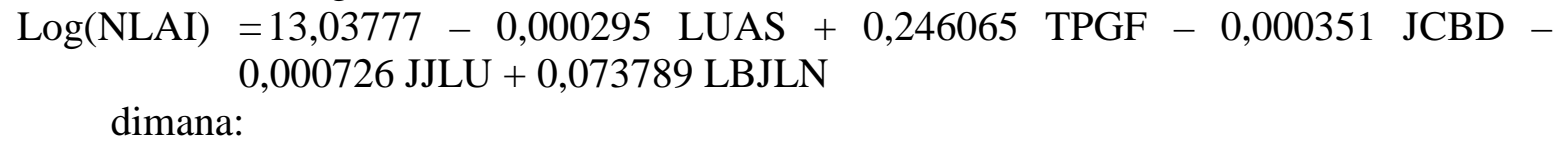

NLAI = Nilai Tanah yang menjadi objek penelitian dalam satuan rupiah setiap meter perseginya

LUAS = Luas tanah yang menjadi objek penilaian dan diukur dengansatuam meter persegi

TPGF $=$ Topografi bidang tanah yang menjadi obejk penelitian dengan memperhatikan tingkat kemiringan dan di aplikasikan sesuai tingkat kemiringan

$\mathrm{JCBD}=$ Jarak tanah ke Central Bisnis Distrik terdekat yang dihitung dalam satuan meter

JJLU = Jarak tanah ke jalan utama terdekat yang dihitung dalam satuan meter

LBJL = Lebar jalan di sekitar bidang tanah yang dihitung dalam satuan meter

Konstanta bernilai positif dan signifikan pada tingkat keyakinan 95\%. Ini sesuai dengan teroi yang menyatakan tanah tetap bernilai dalam kondisi apapun (ketika semua variabel diabaikan). Hal ini menyiratkan bahwa tanah merupakan sesuatu yang sangat 
bernilai karena sangat penting bagi kehidupan manusia. Hasil uji tersebut mendukung teori pendapat Jhon Salindeho (1993:23) merupakan suatu benda bernilai ekonomis menurut pandangan bangsa Indonesia, benda ini pula yang sering memberi getaran di dalam kedamaian dan sering pula menimbulkan guncangan dalam masyarakat.

Pengaruh luasan tanah secara statistik berpengaruh negatif terhadap nilai tanah pada tingkat keyakinan $95 \%$. Artinya, kan terjadi penurunan nilai tanah per meter persegi apabila luas tanah yang dijual semakin besar. Hasil regresi menunjukkan arah atau tanda koefisien variabel luas tanah adalah negarif, hal ini sesuai dengan teori dan penelitian yang dilakukan oleh Bjorklund et. al.. (2006) dan Muchamad Imam Bintoro. (2005); bahwa luas tanah berpengaruh negatif terhadap nilai tanah per meter persegi yang akan di jual. Penjualan tanah dalam luasan yang besar cenderung sangat dipengerahui oleh kemampuan masyarakat sekitar, sehingga semakin besar luasan tanah yang ditawarkan untuk dijual akan berdampak semakin rendahnya harga tanah per meter perseginya. Disamping tanah yang memiliki luas tanah yang besar berdampak pada liquiditas tanah tersebut yang rendah.

Koefisien regresi variabel aksesibilitas berupa lebar jalan disekitar bidang tanah menunjukkan bahwa setiap penambahan lebar jalan disekitar bidang tanah selebar 1 meter akan menambah nilai tanah sebesara $18,51 \%$.

Aksesibilitas berupa lebar jalan menuju lokasi properti riil obyek lelang secara statistik berpengaruh positif terhadap hasil lelang pada tingkat keyakinan $95 \%$. Hal ini sesuai dengan teori Fanning dkk. (1994: 59) yang menyatakan bahwa aksesibilitas properti riil yang semakin baik lebih diminati dan oleh karenanya akan meningkatkan potensial nilai pasar sekaligus probabilitas terjualnya properti riil dimaksud. Oleh karena pada dasarnya aksesibilitas merupakan aspek spesifik dari lokasi, maka hal tersebut juga sejalan dengan pengaruh lokasi dalam penelitian Agus Prasetyo(2009); Adi Suranto (2009); Lita Sari Barus (2010); dan Wijito, dkk (2010). Hasil penelitian yang sama juga ditunjukkan oleh dan Muchamad Imam Bintoro(2015) bahwa lebar jalan memiliki pengaruh positif terhadap nilai tanah. Aksesibilitas berupa lebar jalan berkaitan dengan preferensi calon pembeli yang akan membeli bidang tanah. Calon pembeli cenderung lebih memilih tanah yang memiliki aksesibilitas berupa jalan yang lebar karena kemudahan dalam mobilitas baik orang, barang ataupun jasa dari dan menuju bidang tanah tersebut apabila dimanfaatkan. Dengan kata lain, semakin lebar jalan disekitar bidang tanah, maka keinginan calon pembeli untuk memilki bidang tanah tersebut akan semakin tinggi sehingga berdampak pula pada peningkatan akan nilai bidang tanah.

\section{Kesimpulan}

\section{KESIMPULAN DAN SARAN}

Hasil yang dapat disimpulkan dari penelitian ini adalah sebagai berikut.

1. Tambahan besaran luasan tanah sebesar $1 \%$ akan menurunkan nilai tanah per meternya sebesar $0,7 \%$. Hal ini membuktikan bahwa semakin luas bidang tanah yang ditawarkan untuk dijual akan menyebabkan nilai tanah permeternya semakin rendah.

2. Tanah dengan topografi rata mempunyai nilai 0,76 kali lipat lebih tinggi dibanding tanah dengan topografi tidak rata dengan anggapan variabel lain tetap yang berarti telah sesuai dengan hipotesis

3. Jarak tanah ke CBD berpengaruh negatif terhadap nilai tanah yang berarti telah sesuai dengan hipotesis. Tambahan jarak tanah ke CBD sebesar $1 \%$ akan menurunkan nilai 
tanah per meter sebesar 0,1\% dengan anggapan variabel lain tetap. Semakin dekat dengan CBD nilai tanah akan semakin tinggi

4. Jarak tanah ke jalan utama berpengaruh negatif terhadap nilai tanah yang berarti telah sesuai dengan hipotesis. Tambahan jarak tanah ke jalan utama sebesar $1 \%$ akan menurunkan nilai tanah per meter sebesar 0,2\% dengan anggapan variabel lain tetap. Semakin dekat dengan jalan utama maka nilai tanah semakin tinggi.

5. Lebar jalan berpengaruh positif terhadap nilai tanah. Hal ini telah sesuai dengan hipotesis. Tambahan lebar jalan sebesar 1\% akan menaikkan nilai tanah per meter sebesar $18,51 \%$ dengan anggapan variabel lain tetap. Semakin lebar jalan maka nilai tanah semakin tinggi.

\section{Saran}

Saran yang bisa diberikan dari hasil penelitian ini adalah sebagai berikut.

1. Bagi para penilai hendaknya mempertimbangkan penggunaan variabel-variabel yang dipakai pada penelitian ini dalam penilaian tanah dengan kondisi lokasi serupa. Koefisien-koefisien dari variabel yang dihasilkan hendaknya dijadikan sebagai angka adjustment dalam penilaian untuk meminimalkan faktor subjektifitas dalam penilaian.

2. Pemerintah setempat dan swadaya masyarakat hendaknya berupaya untuk memperbaiki akses menuju jalan utama dengan cara membuka jalan-jalan baru dan memperbaiki kualitas jalan yang sudah ada. Hal ini juga bertujuan agar aksesibilitas penduduk lebih merata.

3. Pemerintah setempat hendaknya membuka akses jalan dan angkutan umum sebanyak mungkin melewati CBD.

4. Kesimpulan bahwa luasan tanah berpengaruh negatif hendaknya dijadikan acuan bagi masyarakat yang ingin menjual tanah diharapkan mempertimbagkan luasan bidang tanah yang tidak terlalu besar dalam melakukan penawaran tanah. Perlu studi lebih lanjut untuk mengetahui faktor penyebab mengapa luasan tanah yang besar menyebabkan penurunan nilai terhadap tanah.

5. Kesimpulan nilai tanah yang rata nilainya jauh lebih tinggi dibanding nilai tanah yang tidak rata mengisyaratkan bahwa penjual tanah hendaknya mengkondisikan tanah yang dijualnya dalam kondisi rata sehingga nilai jualnya menjadi lebih tinggi. Sebaliknya, bagi masyarakat yang ingin membeli tanah diharapkan mempertimbangkan kondisi tanah yang tidak rata sebagai faktor pengurang dalam melakukan penawaran tanah. Perlu studi lebih lanjut yang memperhitungkan biaya perataan tanah dan nilai tanah yang rata sebagai bahan pertimbangan untuk mendapatkan nilai transaksi yang menguntungkan.

\section{DAFTAR PUSTAKA}

Accetta, G.J., 1998, Supporting capitalization Rates, The Appraisal Journal. October, 371374.

AIREA, 2001, The Appraisal of Real Estate, American Institute of Real Estate Appraisal, Chicago. 
Adrian Sutawijaya, 2004, Analisis Faktor-Faktor yang Mempengaruhi Nilai Tanah Sebagai Dasar Penilaian Nilai Jual Obyek Pajak (NJOP) PBB di Kota Semarang, Fakultas Ekonomi Universitas Terbuka.

Agus Prsetyo, 2009, Analisis Berbagai Faktor yang Mempengaruhi Nilai Properti Residensial (Studi pada Kecamatan Depok, Kabupaten Sleman, Daerah Istimewa Yogyakarta Tahun 2008), Tesis Pasca Sarjana UGM, Yogyakarta.

Andi Taufikurnia, 2012, Tingkat kapitalisasi tanah pertambakan air payau dan faktorfaktor yang mempengaruhinya, Universitas Gajah Mada.

Baranyai, Vinogradov, et. al, 2012, Regional Study Of The Land Price And Land Value In Hungary - Based on The Experience of Farm Accounting Data Network, Acta Carolus Robertus 4 (2)

Bintoro Imam Muchamad, 2015, Analisis Faktor-Faktor Yang Mempengaruhi Nilai Tanah Di Kecamatan Depok, Kabupaten Sleman, Daerah Istimewa Yogyakarta, Universitas Muhammadiyah Yogyakarta

Bjorklund, Kicki, John Alex Dadzie, dan Mats Wilhelmsson, 2006, "Offer price, transaction price, and time-on-market", Property Management Journal, Vol. 24, No. 4, 415-426.

Bible, Douglas $S$ and Chengho Hsieh. 1999. Determinant of Vacant Land Values Implication for Apprisers. The Appraisal Journal. Volume LXVII. Number 3, 264268. Appraisal Institute.

Britton, William, Keith Davies, and Tony Jhonson. 1980. Modern Methods of Valuation of Land Houses and Building. $7^{\text {th }}$ edition. The Estate GazetteLimited: London.

Budi Prasetyo, 2007, Perbadningan Pengaruh Jarak Langsung dan Jarak Rute pada Prediksi Model Nilai Tanah Perkotaan di Kota Batam Provinsi Kepulauan Riau, Tesis Pasca Sarjana UGM, Yogyakarta.

Cooper, John M., 2002, Asset Appraisal/ Valuation for Financial Restructuring, Modul Pelatihan, Indonesia-Australia Specialized Training Project Phase.

Chikita Yusuf Widhaswara, 2015, Faktor-Faktor yang Mempengaruhi Perubahan Nilai Tanah dan Bangunan Pada Suatu Properti (Studi Kasus Perumahan Galaxi Bumi Permai - Surabaya). Institut Teknologi Sepuluh Nopember

Eckert, Joseph K. 1990. Property Appraisal and Assesstment Administration. The International Association of Assessing Officers: USA.

Gujarati, Damodar, N., 2004, Basic Econometrics, Fourth Edition, McGraw-Hill International Edition, New York.

Handayani, Tuti, 2003, Analisis Tingkat Kapitalisasi Nilai Rumah dan Faktor Faktor yang Mempengaruhinya di Kabupaten Lombok Timur, Tesis Pasca Sarjana UGM, Yogyakarta.

Harjanto, Budi, 2000, Analisis Nilai Pasar Tanah Pertanian Melalui Pendekatan Ground Rent Capitalization serta Faktor-Faktor yang memepengaruhinya, Laporan Penelitian UGM, Yogyakarta.

Hussey, Jill and Roger Hussey. 1997. Business Research. Palgrave: New York.

Insukindro, 2001, Modul Pelatihan Ekonometrika Dasar, Program Magister Sains, Universitas Gajah Mada, Yogyakarta.

Jhon Salindeho, 1993, Masalah Tanah Dalam Pembangunan, Yogyakarta: Penerbit Sinar Grafika 
Jud, G Donald, and Winkler Daniel, T., 2004, The Capitalization Rate of Commercial Property and Market Returns, The Journal of Real Estate Research, Vol 10, 509517.

Kelsall, D.D., 2008, Loading Capitalization Rates and Discount Rates for Property Taxes and Other Expenses Items, The Appraisal Journal, April, 171-178.

Maddala, G.S., 2001, Introduction to Econometrics, Third Edition, John Wile \& Sons Ltd., England

Lita Sari Barus, 2010, Identifikasi dinamika harga lahan di kawasan cipadu Kota Tangerang. Tesis Pascasarjana UGM, Yogyakarta

Wijito Listiyarko, 2012, dkk, Penerapan Model Hedonic Dalam Penentuan Nilai Tanah Sebagai Referensi Dalam Penilaian Barang Milik Negara dan Harga Limit Lelang, Kajian Akademis BPPK, Kementerian Keuangan Republik Indonesia.

The Green Book, Appraisal and Evaluation in Central Government, Treasury Guidance, London: TSO,

Martin JH, dan Sussman, M.W. 1997, The Twelve RS: An Overview of Capitalization Rate Derevation, The Appraisal Journal, April 149-155.

Nurhayati. 2004. Pengaruh lingkungan Kampus UII Terpadu Terhadap Nilai Tanah. Tesis $S$-2. Program Pascasarjana UGM. Tidak dipublikasikan.

Nuril Fiki Aulia, 2005, Faktor-Faktor Yang Mempengaruhi Nilai Tanah Kajian Nilai Tanah Lingkungan Kampus dan di Sekitar Lingkungan Kampus (Studi di Kawasan Jatinangor Sumedang Jawa Barat), Tesis Pasca Sarjana UGM, Yogyakarta

Peraturan Menteri Keuangan Republik Indonesia nomor 166 /PMK.06/2015 Tentang Penilaian Barang Milik Negara, Direktorat Jenderal Kekayaan Negara Kementerian Keuangan Republik Indonesia.

Ritohardoyo Su, Prof. Dr. M.A. 2013. Penggunaan dan Tata Letak Tahan. Yogyakarta: Penerbit Ombak

Saripta, Baiq, 2003, Analisis Tingkat Kapitalisasi Pertokoan dan Fator-faktor yang Mempengaruhinya di Daerah Kota Mataram. Tesis Pascasarjana UGM, Yogyakarta.

Soeparjanto, 2018. Modul Dasar Penilaian, Departemen Keuangan Republik Indonesia Badan Pendidikan Dan Pelatihan Keuangan Pusdiklat Keuangan Umum.

Suranto Adi, 2009, Analisis Pengaruh Keberadaan Terminal Bus Terhadap Nilai Tanah di Wilayah Sekitarnya (Studi Pada Terminal Bus Kartasura Tahun 2003 - 2007), Tesis Pascasarjana UGM.

Sutarmin, 2012, Determinan Nilai Likuidasi Real Property (Studi Eksekusi Lelang PUPN Pada Kantor Pelayanan Kekayaan Negara dan Lelang Madiun Tahun 2008 2010), Tesis Pascasarjana UGM

Undang-Undang Republik Indonesia Nomor 5 Tahun 1960 tentang Peraturan Dasar Pokok-Pokok Agraria, Kementerian Tata Ruang dan Agraria/ Badan Pertanahan Nasional

https://id.wikipedia.org/wiki/Sulawesi_Utara

http://prayudho.wordpress.com/2009/11/05/teori-lokasi/

www.djkn.kemenkeu.go.id/ 